\title{
Using focus groups to investigate service quality determinants for customer satisfaction in selected university libraries in Sri Lanka
}

\author{
Chaminda Jayasundara', Patrick Ngulube ${ }^{2}$ and Mabel K Minishi-Majanja ${ }^{3}$ \\ Department of Information Science, University of South Africa \\ chaminda@lib.cmb.ac.lk; ngulup@unisa.ac.za;majanmk@unisa.ac.za
}

\begin{abstract}
Received: 10 May 2010
Accepted: 16 October 2010

This study aimed at establishing service quality determinants which may affect customer satisfaction in university libraries in Sri Lanka. Using the literature, II 3 service quality determinants were identified. These were then reviewed by eight focus groups in four different universities. Forty of the determinants were perceived to be applicable to their context. The participants also added 14 quality requirements which they thought were not provided for in the list. Finally, the content and face validity of the 54 determinants were evaluated by a panel of experts who ultimately reduced them to 50 . This study recommends the use of the identified quality determinants by library administrators and policymakers in the higher education sector in Sri Lanka to gauge the levels of customer satisfaction and assure quality of service.
\end{abstract}

Keywords: Customer satisfaction; service quality determinants; relationship management; service quality; university libraries; user satisfaction

\section{Introduction}

Improving services of libraries and identifying appropriate criteria for evaluating the quality of services rendered to users or customers is essential. Providing quality service means being able to view services from the customers' points of view and then meeting their expectations (Quinn 1997). Paying attention to service quality generally enables an organisation to develop a partnership with its customers to gain a competitive edge (Hernon \& Nitecki 200I). Besides competing with other service providers, present day libraries may experience a sharp decline in library usage as customers find other avenues to access information, rather than visiting their local libraries.

The application of managerial tools such as service quality in academic libraries may enable them to enjoy the same benefits as the business sector (Hernon \& Altman 1996). Businesses generally aim to satisfy their key stakeholders, such as suppliers, customers and employees. Similarly, no academic library will easily survive if it fails to recognise and meet the needs of its customers such as students, academics and other stakeholders. This underscores the need for service quality in the academic library sector in order to achieve greater satisfaction. The use of appropriate service quality determinants to meet the expectations of customers may assist university libraries to adequately overcome some service quality concerns. There are a number of models that have been adopted from management literature and used to measure the effectiveness of library services in many organisations. However, the applications of these models in the library and information service sector have not been significantly successful (Filiz 2007; Hernon \& Altman 1996; Jayasundara, Ngulube \& Minishi-Majanja 2009).

The concept of service quality is defined in a number of different ways in other disciplines, but it is generally defined by researchers in library and information sciences as the assessment of the difference "between a customer's expectations and the customer's perceived sense of actual performance" (Calvert 200 I: 732). In other words, service quality may be perceived as a means of reducing the gap between customer expectations and the service actually provided (Calvert \& Hernon 1997:408; Hernon 2002:225). Service quality in higher education libraries is usually associated with the question of customer satisfaction, which in turn is based upon customer perceptions of service quality (Altman \& Hernon 1996; Cullen 200I). Customer satisfaction is an important measure of service quality in libraries (Filiz 2007).

The assessment of service quality provides an important feedback for libraries to assess and improve the service provided to its customers. Employing customer evaluations to measure the quality of library services has been a widely accepted concept since the last decade (Harwood \& Bydder 1998; Martensen \& Granholdt 2003; Shi, Holahan \& Jurkat 2004). Although the quality element has been firmly established in the academic library sector for at least two decades,

I. Chaminda Jayasundara $(\mathrm{PhD})$ recently graduated from the Department of Information Science, University of South Africa, Pretoria, and is Head of E-learning Department, Central Library, University of Colombo, Sri Lanka.

2. Patrick Ngulube (PhD) is a Professor of Information Science, University of South Africa, Pretoria and editor-in-chief of the ESARBICA Journal: Journal of the Eastern and Southern Africa Regional Branch of the International Council on Archives.

3. Mabel K Minishi-Majanja (DPhil) is an Associate Professor and Chair, Department of Information Science, University of South Africa, Pretoria. 
measuring customer satisfaction from the service quality perspective has not been comprehensively used by the university library management in developing countries, as is evident from the paucity of literature in the field.

\section{Service quality in the literature}

Defining and modelling service quality are generally acknowledged to be more difficult than modelling of the quality of goods because of the intangible nature of services. However, there are two popular service quality models that have been used worldwide for measuring service quality (Bergman \& Klefsjo 1994 cited in Hofman \& Worsfold 1996). They are SERVQUAL developed by Parasuraman, Zeithaml and Berry (1988) and SURVPREF the brainchild of Cronin and Taylor (1992). SERVQUAL or the gap model defines service quality as a function of the gap between customers' expectations of a service and their perceptions of the performance of actual service delivery by an organisation. Using the domains in the SEVQUAL model, SERVPREF was used to measure service quality and customer satisfaction in banking, pest control, dry cleaning and fast food sectors.

Since the 1990s, many researchers have tried to use SERVQUAL to measure library service quality in different settings, but failed to produce reliable and valid results. Carman (1990) found that the SERVQUAL determinants and domains were inconsistent across industries and suggested that the instrument should be customised for each service industry. In consequence, LibQUAL has emerged in library and information science to fill the deficiency gaps of the SERVQUAL model. LibQUAL, which is a modified version of SERVQUAL, was designed on the basis of the underlying methodology of SERVQUAL (Cook, Heath \& Thompson 200I). These generic models mainly focus on service quality and have not given priority to the construct of customer satisfaction. Although LibQUAL emerged to measure the service quality in libraries, it needs to be customised to the domain that is being investigated.

As SERVQUAL, LibQUAL and SERVPREF are generic models that were not particularly developed for a specific context such as the libraries in Sri Lanka, it is first important to identify the quality determinants in relation to the context of which they would be applied before adopting them wholesale and retail. Further, these models are static in nature and they fail to accommodate the inherent dynamism of customer satisfaction and service quality in a given context. The focus of the delineation of customer satisfaction is general, and they neglect the customers' real perspectives in relation to their specific contextual environments. There is a need to look into quality determinants for each context as each context has its own unique set of quality determinants (Jabnoun \& Khalifa 2006; Prayag 2007; Tsoukatos \& Rand 2007; Zhao, Xie \& Leung 2002) with different levels of importance (Feinburg \& de Ruyter 1995). Another argument is that the construct of service quality, which has been developed in one culture, may differ from other cultural settings (Payne-Palacio \& Theis 2005; Spears \& Gregoire 2004).

While the literature is replete with empirical studies on service quality in general, there is a scarcity of empirical studies relating specifically to service quality determinants in university libraries in a specific context. Consequently, there is a need to obtain customers' views on satisfaction in relation to service quality in order to accommodate the inherent dynamism of their constructs and contexts.

\section{Context and scope of the study}

The University of Colombo (UC) and University of Sri Jayewardenepura (USJP) located in Colombo, the capital city of Sri Lanka and two other universities located in the outer regions, that is the University of Ruhuna (UR) in the Southern province and the Rajarata University of Sri Lanka (RUSL) located in the North central province of the country were selected as case studies to determine service quality determinants which may impact on customer satisfaction. The four universities were selected because they fairly represent the higher education landscape in Sri Lanka. They represent a cross section of the university in that country.

The first university library in Sri Lanka was established in 1942 at the University of Colombo, and it has now expanded to 31 libraries attached to I5 national universities and 16 higher educational institutions (University Grants Commission of Sri Lanka statistics 2007). The university libraries in Sri Lanka are managed within the framework of the Universities Act No. 16 of 1978. The mission of the university libraries is to provide support for teaching, learning, research, and community engagement. The collections of the university libraries are built to meet specific research and informational needs of the institution's academic programmes. The general policy of university libraries is that the curricula provide the basis on which the library collection is built. Due to this monopoly in the sector, university libraries are likely to have fewer service-oriented provisions and more bureaucratic characteristics in their service provisions. The university library customer may be relatively less satisfied with service provisions of the library.

All the libraries provide services such as lending, reference, periodical information services, interlibrary loans and a variety of services while providing emerging technology-based services such as e-Journals, Web OPACs, Internet and other allied services. The nature and efficiency of information services provided vary from library to library. 
Undergraduate students, members of faculties, research scholars and postgraduate students are the major customers of the libraries. Administrative staff, clerical staff and the allied grades, which comprises of labourers, attendants, and binders are not prominent members as they rarely visit the libraries to fulfil their specific informational needs.

Even though a range of information and customer services can be clearly found in all libraries, the image of the university libraries in Sri Lanka is weak because they have failed to meet the customer expectations on library services (Silva 1995). Although, Nanayakkara (2008) recently pointed out that the tangible resources and intangible services available in the Sri Lankan university libraries are of high standard compared to the other libraries in the Indian subcontinent and some other developing regions in Asia, university libraries and their services have a low status and are undervalued. The situation is complicated by the fact that benefits for customers derived from library services are difficult to measure and hence to manage. Furthermore, "recent political and economic events have dragged libraries into the value-driven environment, from which they are unlikely ever to escape" (Nicholas 1996:6). As libraries are now on the same cost-conscious foothold as any other business, they are subject to matters concerning customer care and cost benefit. Quality assurance may assist libraries to improve their image and the quality of their services.

A quality assurance practice was introduced to the university library sector of Sri Lanka in 2007. The Quality Assurance and Accreditation Council (QAA) of Sri Lanka stipulates that output indicators, process indicators and input indicators should be the three main components for quality measurements of libraries. Customer surveys on library services, which mainly focus on customer satisfaction have been recognised as an important output indicator for university libraries (Quality Assurance and Accreditation Council 2008). Thus, library assessment helps the library administrators to understand what is working well or poorly and what are its current strengths and weaknesses. Customer assessment can provide invaluable data to libraries for re-orienting their collections, services and activities for effectively meeting information needs of their valued customers (Padmasiri, 1997; Shi \& Levy, 2005).

The traditional measures of library evaluation such as the number of books and serials on the shelves or titles bought per year and so on were no longer valid (Nicholas 1996). In Sri Lanka, quality of the university library service is still measured by the statistics that are reported annually to the university administration in the form of funds spent on collection development, number of professional librarians employed, number of customers (external and internal) utilized the service and the queries answered by librarians (University of Colombo annual report 2003). Nicholas (1996) argued that these measures need to be changed since the success or effectiveness of a library can be mainly determined through customer satisfaction. Continuous interaction between library customers and information providers is essential for developing a better understanding of information needs of customers, acceptance and use of library collections, services and facilities and their opinion about the utility of various information sources. Such feedback is necessary for conceptualization, planning, and implementation of information systems and services for an institution (Verhoeven, Boerman \& Jong 1995).

Recently, there has been increasing pressure on libraries to assess the degree to which their services demonstrate quality, rather than relying on traditional statistics, based on tangible products of the library. Several individual libraries have conducted independent measures of customer satisfaction and service quality in libraries. Even so, there is no universal and systematic reporting mechanism for the results (Cook \& Thompson 2000: 248) in libraries. As library service assessment processes develop and progress, both researchers and library administrators have begun to examine current practices and to seek to experiment with better assessments. While a number of researchers have evaluated the constructs of customer satisfaction and service quality to model satisfaction in other areas, there is a dearth of research studies in the field of university libraries to identify service quality determinants in relation to customer satisfaction, in order to encourage stakeholders to develop appropriate measures for evaluation.

\section{Statement of the problem}

The problem addressed by this study is twofold. Firstly, despite the importance of acknowledging the concept of customer satisfaction and its marketing implications, it appears that investigations of customer behaviour focusing on service quality are disproportionately under-represented in library and information services. In the second instance, although the provision of facilities and staffing at university libraries in Sri Lanka appear to be adequate, there seems to be less emphasis on quality service delivery (Quality Assurance Accreditation Council 2008).

The library administrators are left wondering what they can do to satisfy the customers and provide a good quality service as perceived by their valued customers. In order to allocate limited library resources effectively and provide a better service to their users or customers, it would be essential for library administrators to identify customers' priorities among various service quality determinants and to improve these determinants towards greater customer satisfaction.

This study therefore examines different indicators of service quality in relation to customer satisfaction in the university library sector by examining customers' perception of various service quality determinants. The determinants 
developed will provide the means by which internal library operations in Sri Lanka may be tested on their functional efficiency and efficacy and facilitate the application of appropriate corrective or regulatory measures for under developed areas.

While having the potential to improve the quality of library services to improve customer satisfaction and thereby economically contribute to higher benefits, this study also serves as a useful pool of quality determinants which may also serve as tools of reference to library administrators and policymakers in the higher education sector, and setting up a quality assurance scheme for university libraries in Sri Lanka in line with the current quality assurance system (University Grants Commission of Sri Lanka 2007).

The major questions that guided this research were:

- What constitutes customer satisfaction in relation to service quality in university libraries in Sri Lanka?

- What are the service quality determinants that may impact customer satisfaction?

\section{Methodology}

This research seeks to identify service quality determinants that may result in customer satisfaction in university libraries of Sri Lanka. The pool of quality determinants was identified deductively from the previous research studies, and inductively by asking respondents to describe their attitudes and feelings in relation to service quality. The initial service quality determinants were compiled using an extensive literature survey, which is a common form for determining determinants for analysis (Churchill 1979; Zaichkowsky 1985). As many as II3 quality determinants were identified in studies carried out by Calvert (200I), Calvert (1998), Calvert and Hernon (1997), Cook, Heath and Thompson (200I), Filiz (2007), Harwood and Bydder (1998), Moon (2005), Nimsomboon and Nagata (2003), Nitecki (1996), Tuomi (200I) and Woo (2005) in China, Singapore, New Zealand, United States of America, Turkey, New Zealand, South Africa, Thailand, United States of America, Finland and Hong Kong respectively. These determinants were then discussed in focus groups and among discipline experts to identify those that were specific to university libraries in Sri Lanka.

Focus groups have gained considerable credence as a way of extracting the complexities of consumer research decision making, without creating a threatening environment (Morgan 1996), and are often used as an initial research technique and as a precursor to a larger research project (Smith, Smith \& Clarke 2007). Focus groups were utilised for this research because the existing literature available in relation to the Sri Lankan university context did not provide a sound foundation of service quality determinants from the customer perspective of university academic libraries and its impact on customer attitudes. Flick (1998) and Neuman (1997) and Churchill (1979), suggest that focus groups are useful in exploratory research or in generating new ideas for hypotheses in a permissive, non-threatening environment (Krueger \& Casey 2000).

Eight focus groups, two from each university, were used in the study to gather data. The focus group size in this study was seven users/customers in a particular library. Morgan (1996) and Mosia and Ngulube (2005) recommend six to ten participants for a group, whilst Asquith (1997) suggests a group of less than eight participants. The seven participants chosen consisted of three undergraduate students, two postgraduate students and two academic staff members from the Faculties of Arts universities of Colombo, Sri Jayewardenepura and Ruhuna. At the Rajarata University of Sri Lanka, which does not have postgraduate students, two additional undergraduate students were invited to the group to maintain the size recommended for focus group discussions.

The focus groups were initially selected in consultation with the front office library staff of the selected libraries, based upon the regularity of library visits of these clients and their willingness to participate. As experience is an influential factor in assessing the quality of services, only the students in second, third and fourth years of study were selected for the focus group discussions. Academics with a minimum of one year's experience were also included. Non-academic staff members were also excluded due to their low library usage.

Each individual member of the group was asked to think of any particular service in an academic library of their choice. This step was taken in order to give the focus group members an opportunity to understand better the stages of the service encounter. It was also designed to assist the focus group members to visualise and develop a Walk-Through-Audit (WTA) (Bojanic 1994), which traces the experience of customers and their impression of the service quality from the first to last stages of a service encounter. Next, the focus group participants were requested to identify the quality determinants through the WTA. Then the service quality determinants identified from previous studies were extensively debated in the focus group discussions in order to examine their applicability to both Sri Lanka and the university library sector in particular.

All focus group discussions were conducted until no new information was forthcoming. At the completion of all focus group conversations, a content analysis of the discussions was done through the identification of the content element as

SA Jnl Libs \& Info Sci 2010, 76(2) 
suggested in the literature (Easterby-Smith, Thrope \& Lowe 1991; Gremeler 2004). Fifty four quality determinants were identified through that process.

The determinants identified by focus group discussions were then reviewed by three library and information professionals who were professional university librarians in Sri Lanka and two experts from the field of service marketing. These professionals had more than fifteen years experience, and they held professional qualifications at the master's level and above. The objective of this review process was to remove unclear, biased or repetitive determinants identified in the focus group discussions.

\section{Findings and discussion}

Approximately two-hour discussions were held for each focus group in September 2008. The majority of the participants had substantial years of experience with the university library service, ranging from 2 to 18 years. The majority of respondents were males and were regular library customers in their universities. These qualities of the focus groups helped to enrich and validate the determinants identified through the literature survey, and to generate additional determinants that were more specific to the university library sector in Sri Lanka. The analysis of the focus group discussions yielded a rich inventory of attitudes of library customers in the universities. The outcomes of the discussions were analysed using the following questions:

- Are customers familiar with the concepts of satisfaction and service quality?

- Do customers derive satisfaction from service quality?

- If satisfaction is derived from service quality, what quality determinants promote customer satisfaction?

6.1 Familiarity with the concepts of satisfaction and service quality

Most of the literature on customer satisfaction has endorsed the growing popularity of service quality as a contrivance for developing customer satisfaction. Most commonly, respondents emphasised the need for customer satisfaction with service quality, and one participant described the importance of quality services as follows:

The library is like my second home. And I believe that the people here (library staff) always support me. I've gotten used to coming here so far. Whatever information need I encounter, I can come here and ask either from the people here (library staff) or just select the materials from the shelves. But basically, my satisfaction is merely based on the quality of information resources and the service rendered by the staff. In fact, I know the meaning of these two phrases, I mean customer satisfaction and service quality. (Focus group, University of Ruhuna)

Strong feelings regarding satisfaction and service quality among participants contextualised the discussion of these two constructs: service quality and customer satisfaction. According to one participant, "service quality just leads to my satisfaction" (Focus group, University of Colombo). All participants attending the focus group discussions were adequately familiar with the constructs.

6.2 Why it is necessary to contemplate customer satisfaction in relation to service quality

This research question was investigated by conducting a literature survey and focus group discussions. The discussion presented below is a summary and conclusion of the results of the literature survey and focus group discussions in relation to the above research question.

Customer satisfaction and service quality are said to be interrelated concepts, and satisfaction to be a function of service quality (Hernon \& Altman 1998; lacobucci, Ostrom, \& Grayson 1995). Thus, the important aspect of this relationship is the causality between the two constructs: Which one is antecedent to the other? Does satisfaction cause quality judgment, or does quality judgment cause satisfaction? Since most researchers have agreed that quality judgments cause satisfaction, it may be concluded that service quality is the antecedent of satisfaction (Heskett, Sasser \& Schlesinger 1997; Spreng \& Mackay 1996). The focus groups of the study also confirmed that their satisfaction is also based upon service quality.

6.3 Satisfaction with service quality

Satisfying customers is a core business challenge in every organisation, which university libraries cannot escape. A quality library service basically indicates satisfying the requests of customers accurately, exhaustively and expeditiously (Sharma 200I). Providing excellent service quality is also recognised as a critical business requirement (Vilares \& Coehlo 2003; Voss et al., 2004). As Rosen, Karwan \& Scribner (2003) state, customer satisfaction and service quality are not a corporate offering; they are unconditionally a competitive weapon. This is truly an essential component of corporate profitability and survival (Bolton, Lemon \& Verhoef 2004; Luo \& Homburg 2007; Monk \& Ryding 2007; Newman \& Cowling 1996, cited in Maddern et al., 2007). Traditionally, the Association of Research Libraries (ARL) suggested some evaluation 
criteria based on the objective description of collection sizes and other expenditure-driven matrices in order to measure service quality in libraries, but these do not take into consideration the satisfaction of customers.

The focus groups in all selected universities opined that customer satisfaction and service quality were very important. One of the focus group members said that there is

a clear causal relationship with service quality and if service quality gets upgraded, our (customers) satisfaction will also rise to the top. (Focus group, University of Colombo)

Some of the members, (two from the University of Ruhuna, three from the University of Colombo and one from Rajarata University), stated that the main consideration at the time of receiving information from the library was the satisfaction of customers with the information received. However, they further articulated that service quality was important and that the information they received was adequate to achieve greater customer satisfaction. Therefore, it may be said that ascertaining quality and satisfaction in relation to information resources is imperative.

According to some participants, the quality of information was the primary reason for their satisfaction, even though they said that other service quality determinants may also have an impact on satisfaction. However, the majority of members pointed out that quality of both materials and services are very important and cannot be separated. One participant explained further:

From the time we enter the university library, we seek information. It is generally perceived as problemoriented. We want to find out some information perhaps in consultation with a professional librarian. It is very much customer-led in terms of searching out information, with the satisfaction received from the service and products received. Quality and satisfaction have been combined into one concept irrespective of whether it is material or service; they cannot be separated (Focus group, University of Ruhuna).

Thus, it could be seen that customers perceive satisfaction as being derived from service quality.

6.4 Quality determinants that promote satisfaction

The objective of this question was to generate a pool of determinants specific to the construct of service quality being investigated. All group participants agreed that satisfaction is driven by service quality, and it may also be derived by inclination, to a larger extent. A participant said,

Although I know personally that there is an interrelationship between these two concepts (constructs), I will actively search it out to find whether there is a theoretical implication. In practical circumstances, satisfaction occurs by means of quality not only of the services but also of the products available in our local libraries...but I don't understand that there is a theoretical relationship because my knowledge of contemporary management theories is very poor. I never know the answers to everything in management. (Focus group, University of Sri Jayewardenepura)

Accordingly, even though five participants admitted that they were not very familiar with service quality determinants at first, when the discussion proceeded, they understood the meaning of quality determinants. Subsequently, they were able to explain the quality requirements that they expected from their libraries.

Since this study dealt with the WTA method, which traces the experiences of customers with service quality in university libraries, the questions directed the discussions towards the best and worst experiences in the context of the service and quality determinants that an excellent service should provide. When the participants were requested to describe their experiences with the library service at their universities, the first theme that emerged was the importance of specific information resources on their subject disciplines for teaching and/or learning purposes. The participants had positive experiences when served with relevant materials. A number of members spoke of the difficulties they experienced in finding information necessary for their teaching, learning and research activities. The participants were mainly concerned about not receiving/finding enough information and exact information on what they needed. Thus, the participants emphasised the paramount importance of teaching materials and their quality, rather than other types of service quality. However, they all agreed on the possibility of measuring material quality on the basis of their perceptions of quality.

Some participants complimented the service environment of their libraries. The qualities of caring service and fellowship extended during information search were some of their best experiences. The participants mentioned 
common problems with the service instead of narrating individual incidents and/or personal experience, when asked about their past experiences with the library. They were concerned about limited materials, insufficient service providers at the counters, non-availability of up-to-date and relevant information at the right time, and inflexibility in providing the necessities of requirement-based customer education programmes. The participants also presented their ideas on the quality determinants of an outstanding library service.

The common attitude of approximately half of the participants in all four focus groups was that searching for information was a time-consuming and frustrating activity. Their viewpoint was that they required help from the library staff to obtain the right information in the shortest possible time. Thus, the consensus among the members was that helpfulness, promptness and related qualities are essential for the library staff to contribute towards the achievement of greater customer satisfaction. Many participants complained about the limited accessibility of electronic information for teaching and learning purposes. While some had subsequently received the facilities to access electronic information, most of those employed in the remote universities of Rajarata and Ruhuna had not yet received them.

The researchers analysed the discussions and highlighted the key words and concepts that were directly related to the quality of library services. The contents were thereafter used to explain the determinants relating to service quality. The focus groups also reviewed the 113 determinants of service quality in relation to customer satisfaction identified from the literature survey. They identified between 30 and 40 determinants of service quality that they perceived to be relevant to Sri Lankan university libraries. The determinants that were common to the four institutions are depicted in Figure I.

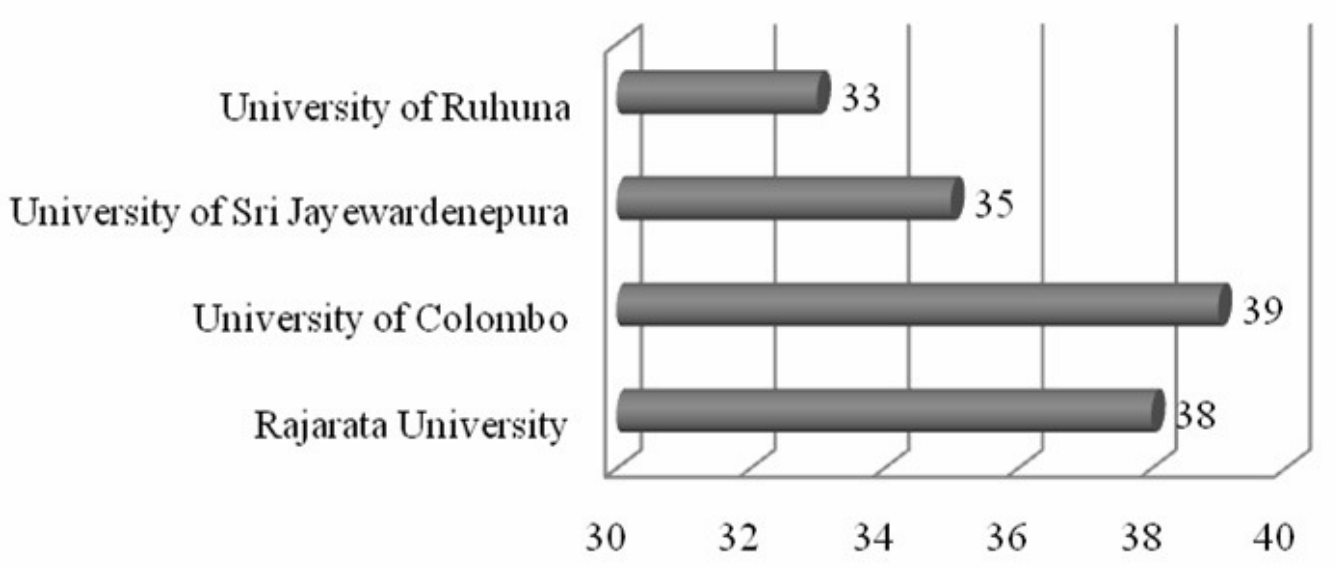

Number of institutions idenfying with the service attribute

Figure 1 Quality requirements identified from past studies

However, apart from the 40 quality requirements based upon the previous studies that they identified the focus groups indicated 14 other quality requirements that they thought were unique to universities in Sri Lanka. The panel of six experts then screened all the quality requirements identified by focus groups for overlap, ambiguity and suitability. The panel found that some of the 40 quality requirements identified from the literature by the respondents overlapped with some of the quality requirements that the respondents thought they were unique to Sri Lankan university libraries. Thus, four out of the fourteen quality requirements they had identified were discarded when finalising the list of quality determinants. All the 50 quality requirements were then transformed into quality determinants using the following criteria. To be selected:

- determinants had to address only a single issue and not be double-barrelled (DeVellis 2003);

- determinants that measure attitudes and behaviour needed not be included in the same scale (Hinkin, Tracey \& Enz 1997);

- determinants had to be short, simple and easy to be understood (DeVellis 2003); and

- negatively worded determinants were avoided or used with considerable caution (DeVellis 2003).

SA JnI Libs \& Info Sci 2010, 76(2) 
Accordingly, from the quality statements gathered from focus group discussions (10) and the literature (40), the researchers developed a list of 50 determinants indicated below in Table I.

Table I Service quality determinants

\begin{tabular}{|c|c|c|c|}
\hline No. & Determinant & No. & Determinant \\
\hline I & Staff approachability & 26 & Convenient opening hours \\
\hline 2 & Complaint responsiveness & 27 & Good ventilation \\
\hline 3 & Cultural sensitivity & 28 & Good functional furniture \\
\hline 4 & Courtesy of the staff & 29 & Good lighting \\
\hline 5 & Personal attention to customers & 30 & Quick reshelving \\
\hline 6 & Being informed about new services & 31 & Quietness in the library \\
\hline 7 & Supportive atmosphere & 32 & Air-conditioning \\
\hline 8 & Follow-up service & 33 & Access to computers \\
\hline 9 & Proper coordination by the staff & 34 & Audiovisual equipment in good condition \\
\hline 10 & Staff knowledgeability & 35 & Modern equipment \\
\hline II & Promptness of the staff & 36 & Error-free records in the systems \\
\hline 12 & Contemplative environment & 37 & Effective resource sharing \\
\hline 13 & Physically challenged friendly facilities & 38 & Archival access \\
\hline 14 & Reflective and creative place & 39 & E-journal access \\
\hline 15 & Accessibility to buildings & 40 & Remote access \\
\hline 16 & Helpful directional signs & 41 & Reasonable fine structure \\
\hline 17 & Comfortable and inviting place & 42 & Customer education programmes \\
\hline 18 & High quality information resources & 43 & Transactional confidentiality \\
\hline 19 & Collection completeness & 44 & Library guides \\
\hline 20 & Convenient access to collections & 45 & Well-organised Web site \\
\hline 21 & Diversified general readings & 46 & Useful library Web site \\
\hline 22 & Collection comprehensiveness & 47 & Needs well-oriented Web site \\
\hline 23 & Current information & 48 & Accurate OPAC \\
\hline 24 & Needs-oriented resources & 49 & Easy OPAC \\
\hline 25 & Good sanitary facilities & 50 & Up-to-date OPAC \\
\hline
\end{tabular}

\section{Conclusions and recommendations}

The university library should ensure that the university community makes use of the resources for the right purpose, and that the library provides high quality services to this wider customer community (Poll \& Boekhorst 1996). By identifying service quality and customer satisfaction from the customers' perspectives, library service can strengthen its quality of services, as expected by customers. To collate the opinions of customers on current library services, the libraries can reorient and regulate the services to serve the customers better.

In general, customers' expectations and perceptions, as well as performances of services, are formed by service quality determinants that are specific to each service organisation. These dimensions should have conceptual and empirical relevance to the construct of customer satisfaction in university libraries. Deductive and inductive determinant generation methods were found to be useful in identifying the quality determinants that are connected to customer satisfaction. Fifty quality determinants were identified in the study as significant. These determinants are more than the number of determinants identified in the LibQUAL model. Though there are some similar determinants found from the LibQUAL model, some are very particular to the context of Sri Lankan Universities. Thus, it brings into play the idea that context may have had a significant effect to the customer perspectives on service quality and customer satisfaction.

It is very important for library administrators to understand the determinants that play a role in the overall satisfaction judgments of library users. Important quality determinants were identified by which customers mainly evaluate their 
overall performance to form satisfaction. Therefore, library administrators are required to maintain or increase the level of customer satisfaction in these determinants and to assign high priority to them. The strong performance of all quality determinants, as identified in the study, may be a decisive factor that ensures overall customer satisfaction in relation to library services. Thus, it becomes necessary to arrange the resources and operations in each of the determinant to optimise the functioning of the service patterns in order to provide a satisfactory service to the customers.

Considering that this study was conducted in Sri Lanka, further expansion and comparison involving university libraries not based in Sri Lanka, with differing work practices, methods, customer communities, and library resources, needs to be conducted. Culture may have a significant influence on service quality and customer satisfaction as well as quality determinants. This then opens another line of comparative research that could help libraries understand global variants of issues pertaining to customer satisfaction with service quality. As a result, a common structure of determinants for libraries could be established and the possibility of using them as benchmarks of any service quality/customer satisfaction instrument can be further explored.

This research focused on the quality determinants of the construct of customer satisfaction, based on a cross-sectional analysis at a single point in time. The results reinforce some of the findings in the existing literature that point to service quality in university libraries as being the key drivers of customer satisfaction. However, some of the service quality determinants are exclusive to this study, that is, they cannot be observed in other similar studies that have been conducted. These determinants must also be considered by service providers and policymakers in university libraries in Sri Lanka in order to harness the process of enhancing ultimate customer satisfaction within their libraries. Whilst not detracting from preceding research studies conducted in the field, this study has demonstrated significant implications for researchers and library administrators in the country in understanding the importance of individual quality determinants within the specific service spectrum of university libraries, in order to provide ultimate satisfaction for customers with a quality library service.

\section{References}

Asquith, JAL. 1997. The effects of group size on the outcome of focus group sessions. Management Research News, 20(I2): I15.

Baker, MJ. 200I. Selecting a research methodology. The Marketing Review, I(3): 373-397.

Bojanic, DC. 1994. Measuring service quality in restaurants: an application of the SERVQUAL instrument. Journal of Hospitality and Tourism Research, I8(I):3-14.

Bolton, RN, Lemon, KN \& Verhoef, PC. 2004. The Theoretical underpinnings of customer asset management: a framework and propositions for future research. Journal of the Academy of Marketing Science, 32(3): 27I-292.

Brady, MK, Cronin, J \& Brand, RR. 2002. Performance-only measurement of service quality: a replication and extension. Journal of Business Research, 55(I): |7-31.

Calvert, PJ. 1998. A different time, a different country: an instrument for measuring service quality in Singapore's polytechnic libraries. Journal of Academic Librarianship, 24: 432-437.

Calvert, PJ. 200I. International variations in measuring customer expectations. Library Trends, 49(4): 732-757.

Calvert, PJ \& Hernon, P. 1997. Surveying service quality within university libraries. Journal of Academic Librarianship, 23: 408-4I5.

Carman, JM. 1990. Consumer perceptions of service quality: an assessment of SERVQUAL dimensions. Journal of Retailing, 66(I): 33-56.

Churchill, GA. 1979. A paradigm for developing better measures of marketing constructs. Journal of Marketing Research, I6(I): 64-73.

Cook, C \& Thompson, B. 2000. Reliability and validity of SERVQUAL scores used to evaluate perceptions of library service quality. The Journal of Academic Librarianship, 26(4): 248:58.

Cook, C, Heath, FM \& Thompson, B. 200I. Users' hierarchical perspectives on library service quality: a "LibQUAL+" study. College and Research Libraries, 62: 147-153.

Cronin, JJ \& Taylor, SA. 1992. Measuring service quality: a re-examination and extension. Journal of Marketing, 56(3): 55-68.

Cullen, R. 200I. Perspectives on user satisfaction survey. Library Trends, 49(4): 662-686.

Dabholkar, PA, Shepherd, CD \& Thorpe, DI. 2000. A comprehensive framework for service quality: an investigation of critical conceptual and measurement issues through a longitudinal study. Journal of Retailing, 76(2): 139-173.

Deshpande, R. 1983. Paradigms lost: on theory and method in research in marketing. Journal of Marketing, 47 (4): $101-110$.

DeVellis, RF. 2003. Scale development: theory and applications. $2^{\text {nd }}$ edition. Thousand Oaks, CA: Sage.

Easterby-Smith, M, Thorpe, R \& Lowe, A. 199I. Management research: an introduction. London: Sage.

Feinburg, RA \& de Ruyter, K. 1995. Consumer-defined service quality in international retailing. Total Quality Management, 6 (I): $61-67$.

Filiz, Z. 2007. Service quality of university library: a survey amongst students at Osmangazi University and Anadolu. [Online]. http://eidergisi.istanbul.edu.tr/sayi5/iueis5m I.pdf (Accessed on 23 March 2008).

Harwood, N \& Bydder J. 1998. Student expectations of, and satisfaction with, the university library. The Journal of Academic Librarianship, 24(2): $|6|-17 \mid$.

Hernon, P \& Altman, E. 1996. Service quality in academic libraries. Norwood, NJ: Ablex Publishing.

Hernon, P \& Nitecki, DA. 2001 . Service quality: a concept not fully explored. Library Trends, 49(4): 687-708.

Hernon, P. 2002. Quality: new directions in the research. Journal of Academic Librarianship, 28(4): 224-23I. 
Heskett, JL, Sasser, WE \& Schlesinger, LA. 1997. The service profit chain. New York: Free Press.

Hiller, S \& Self, J. 2004. Making library assessment work. [Online]. http://www.arl.org (Accessed on I2 July 2009).

Hinkin, TR, Tracey, JB \& Enz, CA. 1997. Scale construction: developing reliable and valid measurements. Journal of Hospitality and Tourism Research, $2 \mathrm{I}(\mathrm{I})$ : 100-120.

Hinkin, TR. 1995. A review of scale development practices in the study of organizations. Journal of Management, 2 I (5): $967-988$.

Hofman, P \& Worsfold, E. 1996. Specification for resource description methods Part 2: selection criteria for quality controlled information gateways, Work Package 3 of Telemetrics for Research project DESIRE (RE I004). [Online]. http:// www.ukoln.ac.uk/metadata/desire/quality/quality.pdf (Accessed on 12 March, 2008).

lacobucci, D, Ostrom, A \& Grayson, K. 1995. Distinguishing service quality and customer satisfaction: the voice of the customer. Journal of Consumer Psychology, 4(3): 277-303.

Jabnoun, N \& Khalifa, A. 2006. A customized measure of service quality in UAE. Managing Service Quality, I5(4): 374-388.

Jayasundara, C., Ngulube, P \& Minishi-Majanja, M. 2009. A theoretical model to predict customer satisfaction in relation to service quality in selected university libraries in Sri Lanka. South African Journal of Libraries and Information Science, 75(2): I79194.

Krueger, R \& Casey, M. 2000. Focus groups: a practical guide for applied research. Thousand Oaks, CA: Sage.

Luo, X \& Homburg, C. 2007. Neglected outcomes of customer satisfaction. Journal of Marketing, 7I: I33-49.

Maddern, H, Maull, R, Smart, A \& Baker, P. 2007. Customer satisfaction and service quality in UK financial services. International Journal of Operations and Production Management, 27(9): 999-1019.

Martensen, A \& Granholdt, L. 2003. Improving library users' perceived quality, satisfaction and loyalty: an integrated measurement and management system. The Journal of Academic Librarianship, 29(3): I40-I47.

Monk, D \& Ryding, D. 2007. Service quality and training: a pilot study. British Food Journal, 109(8): 627-636.

Moon, AE. 2006. LibQUAL $+{ }^{\mathrm{TM}}$ at Rhodes University library: an overview of the first South African implementation. [Online]. http://eprints.ru.ac.za/234/0I/Paper_A-Moon-v5.pdf (Accessed on 3 March, 2008).

Morgan, DL. 1996. Focus groups. Annual Review of Sociology, 22: I29-I56.

Mosia, L \& Ngulube, P. 2005. Managing the collective intelligence of local communities for the sustainable utilisation of estuaries in the Eastern Cape, South Africa. South African Journal for Library and Information Science, 7I (2): I75- I86.

Nanayakkara, L. 2008. A comparative study on marketing of reader services in academic libraries in Asia: with special reference to India, Malaysia, Thailand and Sri Lanka. MLS thesis. University of Colombo, Colombo.

Nicholas, D. 1996. Assessing information needs: tools and techniques. London: Aslib.

Nimsomboon, N \& Nagata, H. 2003. Assessment of library service quality at Thammasat University. [Online] http:// www.kc.tsukuba.ac.jp/div-comm/pdf/report0403.pdf. (Accessed on 23 February, 2008).

Nitecki, D \& Franklin B. 1999. Perspectives on new measures for research libraries. Journal of Academic Librarianship, 25(6): 484-487.

Nitecki, D. 1996. Changing the concept of measure of service quality in academic libraries. Journal of Academic Librarianship, 22(3): $181-190$.

Padmasiri, GR. 1997. Evaluation of reader services in the university libraries in Sri Lanka. MLS thesis. University of Colombo, Colombo.

Parasuraman, A, Zeithaml, VA \& Berry, LL. 1988. SERVQUAL: a multiple-item scale for measuring consumer perceptions of service quality. Journal of Retailing, 64(I): 12-40.

Payne-Palacio, J \& Theis, M. 2005. Introduction to food service. $10^{\text {th }}$ edition. New Jersy: Prentice Hall.

Poll, R \& Boekhorst, P 1996. Measuring quality: international guidelines for performance measurement in academic libraries. London: Saur.

Prayag, G. 2007. Assessing international tourists' perceptions of service quality at Air Mauritius. International Journal of Quality and Reliability Management, 24(5): 492-5I4.

Pritchard, SM. 1996. Determining quality in academic libraries. Library Trends, 44(3): 572-594.

Quality Assurance and Accreditation Council. 2008. Quality assurance handbook- Sri Lankan university libraries. Colombo: Quality Assurance and Accreditation Council.

Quinn, B. 1997. Adapting service quality concepts to academic libraries. The Journal of Academic Librarianship, 23: 359-69.

Riley, M. 2007. Role interpretation during service encounters: a critical review of modern approaches to service quality management. Hospitality Management, 26: 409-420.

Rosen, LD, Karwan, KR \& Scribner, LL. 2003. Service quality measurement and the disconfirmation model: taking care in interpretation. Total Quality Management, I4(I): 3-I4.

Santos, J. 2003. E-service quality: a model of virtual service quality dimensions. Managing Service Quality, I3(3): $233-246$.

Schneider, B \& White, SS. 2004. Service quality: research perspective. Thousands Oaks, CA: Sage.

Sharma, J.C. 200I.Total quality management in library and information services, in Dhawan, SM (ed). Quest for quality. Indian Library Association, Delhi, I66-I7I.

Shi, X \& Levy, S. 2005. A theory-guided approach to library services assessment. College and Research Libraries, 66(3): $266-277$.

Shi, X, Holahan, PJ \& Jurkat, P. 2004. Satisfaction formation processes in library users: understanding multi-source effects. The Journal of Academic Librarianship, 30(2): I22-I3I.

Silva, WRG. 1995. University libraries in Sri Lanka: problems and issues. Journal of the University Librarians Association, I(I): I937.

Smith, G, Smith, A and Clarke, A. 2007. Evaluating service quality in universities: a service department perspective. Quality Assurance in Education. 15(3): 334-35I.

Spears, MC \& Gregoire, MB. 2004. Foodservice organizations. $5^{\text {th }}$ edition. New Jersy: Pearson Education.

Spreng, RA \& Mackoy, RID. 1996. An empirical examination of a model of perceived service quality and satisfaction. Journal of Retailing, 72(2): 20I-2I4.

SA Jnl Libs \& Info Sci 2010, 76(2) 
Tsoukatos, E \& Rand, GK. 2007. Cultural influences on service quality and customer satisfaction: evidence from Greek insurance. Managing Service Quality, I7(4): 467-485.

Tuomi, V. 200I. Quality of academic library services: a customer point of view, EGPA 5-8 September 200I. [Online].: http:// soc.kuleuven.be/io/egpa/qual/vaasa/paper_vaasa_tuomi.pdf (Accessed on 10 March, 2008).

University Grants Commission of Sri Lanka statistics. 2007. Colombo: University Grant Commission of Sri Lanka

University of Colombo annual report. 2003. (Unpublished Document). University of Colombo: Colombo

Verhoeven, AH, Boerman, EJ \& Jong, BM. 1995. Use of information sources by family physicians: a literature survey. Bulletin of Medical Library Association, 83(I): 85-90.

Vilares, MJ \& Coelho, PS. 2003. The employee-customer satisfaction chain in the ECSI model. European Journal of Marketing, 37(I I/I2): 1703-17022.

Voss, C, Roth, AV, Rosenzweig, ED, Blackmon, K \& Chase, RB. 2004. A tale of two countries' conservatism, service quality, and feedback on customer satisfaction. Journal of Service Research, 6 (3): 21 2-23.

Wilson, G \& Sasse, M. 2004. From doing to being: getting closer to the user experience. Interacting with Computers, 16: 697705.

Woo, H. 2005. The 2004 user survey at the University of Hong Kong Libraries. College and Research Libraries, 66(2): I I5-I35.

Zaichkowsky, JL. 1985. Measuring the involvement construct. Journal of Consumer Research, 12(3): 34I-352.

Zeithaml, V \& Bitner, MJ. 2000. Service marketing: integrating customer focus across the firm. $2^{\text {nd }}$ ed. New York, Irwin McGrawHill.

Zhao, X, Xie, J \& Leung, J. 2002. The impact of forecasting model selection on the value of information sharing in a supply chain. European Journal of Operational Research, 142(2): $321-344$. 